\title{
Dynamic analysis of firing mechanism of underwater pistol
}

\author{
Dung Nguyen Thai, Hung Nguyen Van
}

\begin{abstract}
The important problem of designing underwater pistol was analysed and calculated the dynamics of firing mechanism. On the basis of analyzing the performance of the underwater pistol, the paper presents a theoretical model for analysing the dynamics of firing mechanism of underwater pistol with the with the resistance of water acting on firing pin and slide. The result of this research can be applied to design the underwater pistol and underwater firearm.
\end{abstract}

Index Terms-Dynamics, Firing mechanism, Resistance of water, Underwater pistol.

\section{INTRODUCTION}

$\mathrm{T}$ HE underwater pistol is designed to destroy enemy personnel at ranges of up to $20 \mathrm{~m}$ under water (depending on diving depth) [1]. Firing under water is possible from all swimmer positions as well as against surface targets from under water. The pistol is intended for combat swimmers. Two kinds of typical underwater pistol current are HKP11 of Germany (Fig.1a) and SPP-1M of Russian (Fig. 1b) [2].

In Vietnam, the research on underwater pistol is limited and water commando forces have not been equipped with this weapon. The researches are mainly focused on projectile's motion under water. So design underwater pistol has become a hot topic.

Manuscript Received on July 13 $3^{\text {th }}$ 2016. Manuscript Revised December 06 ${ }^{\text {th }}, 2016$.

This research is funded by the state-level project "Design and manufacture underwater pistol and projectile to serve the water commando forces" code: KC.03.TN08/11-15. We are also grateful to our colleagues from Department of Weapons for valuable discussions which help to conduct the study.

Dung Nguyen Thai is Dean of the Faculty of Weapons and Director of the Technical Center for Weapons, Military Technical Academy (e-mail: thaidung1966@gmail.com).

Hung Nguyen Van is with the Department of Weapons, Faculty of Weapons, Military Technical Academy (e-mail: hungnv_mta@mta.edu.vn).

In the design process, the dynamic analysis of firing mechanism is a fundamental problem and very important [3]. So the article focuses on solving this problem with the research object is firing mechanism of SPP-1M underwater pistol.

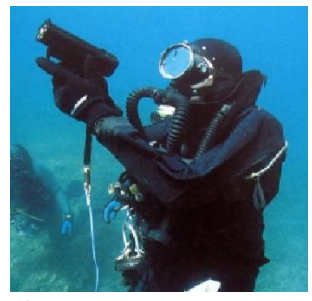

a)

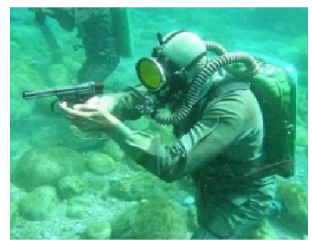

b)

Figure 1. Two kinds of typical underwater pistol

a. HKP11 underwater pistol; b. SPP-1M underwater pistol

\section{DYNAMIC MODEL OF FIRING MECHANISM OF UNDERWATER PISTOL}

The principle of operation of firing mechanism of underwater pistol based on the operation of typical pistol but it is improved to reduce the resistance of water [4]. The firing mechanism of underwater pistol consists of: trigger, slide, slide latch, firing pin, and return spring [5,6,7,8]. Fire process comprising two stages (fig.2):

Stage I: Slide and firing pin moves backward. After pulling the trigger, trigger (1) motions and impacts on B point on the slide (3) to make slide and firing pin moving backwards. Stage I ended when the catch (2) is not contact with B point on on the slide.

Stage II: Slide and firing pin moves forward. After the catch (2) is not contact with B point, Slide (3) and firing pin (4) move forward under the 
action of recoil force of the spring. Firing pin moving forward and strike the primer on bullet to fire.

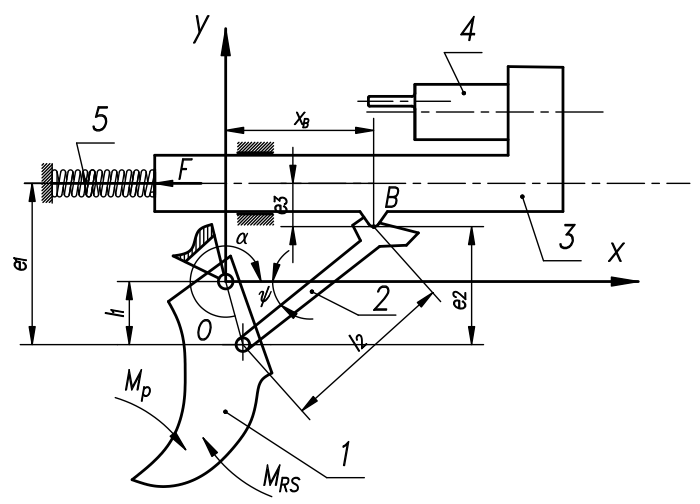

Figure 2. Structural diagram of firing mechanism of underwater pistol

1. Trigger; 2. Slide latch; 3. Slide; 4. firing pin; 5. return spring.

The dynamic model of firing mechanism of underwater pistol is built on the basis of the following assumptions:

1. The objects in the firing mechanism are absolute hard.

2. Ignore the resistance of water acting on the objects rotation in mechanism (Trigger and Slide latch).

3. Ignore the resistance of water acting on the return spring and Slide.

4. Ignore friction force acting on the objects when moving.

5. In stage II, Silde and firing pin are blocked into an object with mass is $m_{3,4}$ and it move forward. Hence the model of firing mechanism is simple model as shown in firgure 3 .

6. Angular velocity of Trigger $\dot{\alpha}$ around origin $\mathrm{O}$ is constant.

In order to analyse dynamics of firing mechanism, at first we consider kinematic in stage I. In Fig. 2 it is seen that:

$$
\left\{\begin{array}{l}
x_{B}=l_{2} \cos \psi+l_{1} \cos \alpha \\
e_{3}=l_{2} \sin \psi+l_{1} \sin \alpha
\end{array}\right.
$$

Derivative equation system 1 we obtain:

$$
\left\{\begin{array}{l}
\dot{x}_{B}=-l_{1} \cos \alpha(\tan \psi+\tan \alpha) \dot{\alpha} \\
e_{3}=l_{2} \sin \psi+l_{1} \sin \alpha
\end{array}\right.
$$

Derivative equation system 2 we obtain:

$$
\left\{\begin{array}{l}
\ddot{x}_{B}=-l_{1} \cos \alpha\left[\begin{array}{l}
(\tan \psi+\tan \alpha) \ddot{\alpha}+ \\
+(1-\tan \psi \tan \alpha) \dot{\alpha}^{2}
\end{array}\right] \\
e_{3}=l_{2} \sin \psi+l_{1} \sin \alpha
\end{array}\right.
$$

In equation systems (1), (2), (3): $\pi \leq \alpha \leq 2 \pi$

In stage I, external forces acting on the systerm as follows (Fig.1):

1. Elastic force of the return spring $F$.

2. The Moment of trigger pull of the gunner $M_{p}$.

3. The resistance moment of trigger spring $M_{R S}$. Assumption $M_{u}$ is useful moment acting on trigger to fire, we have:

$$
M_{u}=M_{p}-F l_{1} \cos \alpha(\tan \psi-\tan \alpha)-\mathrm{M}_{R S}
$$

The total kinetic energy of the system given by [9]:

$$
\begin{aligned}
& T=T_{1}+T_{2}+T_{3}= \\
& =\frac{1}{2} \mathrm{~J}_{1} \dot{\alpha}^{2}+\frac{1}{2} m_{2} l_{1} \dot{\alpha}^{2}+\frac{1}{2} m_{3,4} l_{1}^{2} \cos ^{2} \alpha(\tan \psi+\tan \alpha)^{2} \dot{\alpha}^{2} \\
& =\frac{1}{2}\left[\mathrm{~J}_{1}+m_{2} l_{1}+m_{3,4} l_{1}^{2} \cos ^{2} \alpha(\tan \psi+\tan \alpha)^{2}\right] \dot{\alpha}^{2}
\end{aligned}
$$

where: $T_{1}, T_{2}, T_{3}$ are the kinetic energy of Trigger, Slide latch and Slide

$J_{1}$ is the moment of inertial of Trigger.

$m_{2}$ is the mass of Slide latch.

$m_{3,4}$ is the total mass of slide anf firing pin.

The dynamic equations of firing mechanism are in the Lagrangian form given by [10]:

$$
\frac{d}{d t}\left(\frac{\partial T}{\partial \dot{\alpha}}\right)-\frac{\partial T}{\partial \alpha}=M_{u}
$$

From Eq. (4), (5), (6) we have:

$\left[J_{1}+m_{2} l_{1}^{2}+m_{3,4} l_{1}^{2} \cos ^{2} \alpha(\tan \psi+\tan \alpha)^{2}\right] \ddot{\alpha}+$

$+\frac{1}{2} m_{3,4} l_{1}^{2}\left[\sin 2 \alpha(\tan \psi+\tan \alpha)^{2}-2 \sin 2 \alpha+\right.$

$+2(\tan \psi+\tan \alpha)] \dot{\alpha}^{2}$

$=M_{p}-F l_{1} \cos \alpha(\tan \psi-\tan \alpha)-\mathrm{M}_{R S}$

Because the angular velocity of Trigger is constant (assumption 6), so $\ddot{\alpha}=0$. From Eq.7 we obtain:

$$
\begin{aligned}
& M_{p}=F l_{1} \cos \alpha(\tan \psi-\tan \alpha)+\mathrm{M}_{R S}+ \\
& +\frac{1}{2} m_{3,4} l_{1}^{2}\left[(\tan \psi+\tan \alpha)^{2}+\sin 2 \alpha-2 \sin 2 \alpha\right. \\
& +2(\tan \psi+\tan \alpha)] \dot{\alpha}^{2}
\end{aligned}
$$

In stage II, the article only studying the dynamic of firing pin. So from the Fig.3 we have:

$$
m_{3,4} \ddot{x}=(H-x) k-\left(R_{1}+R_{2}\right)
$$

where $m_{3,4}$ is the total mass of slide and firing pin.

$H$ is the original length of the spring.

$k$ is a constant factor characteristic of the spring. 
$R_{1}, R_{2}$ are resistance forces of water acting on firing pin and its are determined by the formula [11]:

$$
\left\{\begin{array}{l}
R_{1}=\frac{1}{2} \rho A_{1} C_{d 1} \dot{x}^{2} \\
R_{2}=\frac{1}{2} \rho A_{2} C_{d 2} \dot{x}^{2}
\end{array}\right.
$$

where $A_{1}, A_{2}$ are the area of firing pin at nose and body; $\rho$ is density of water; $\dot{x}$ is velocity of firing pin; $C_{d 1}, C_{d 2}$ are drag coefficient. Because the shapes of nose and body section of firing pin are the same, so: $C_{d}=C_{d_{1}}=C_{d 2}=1.2$

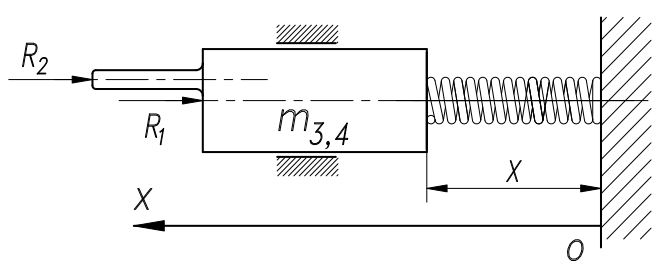

Figure 3. Model of firing mechanism of underwater pistol in stage II

From Eq.9, 10 we have:

$$
\begin{aligned}
& m_{3,4} \ddot{x}=(H-x) k-\frac{1}{2} \rho C_{d}\left(A_{1}+A_{2}\right) \dot{x}^{2} \\
& =(H-x) k-\frac{1}{2} \rho C_{d} A \dot{x}^{2}
\end{aligned}
$$

where $A=A_{1}+A_{2}$ is the section area of firing pin. Initial conditions to solve equations (11) are: $\dot{x}(0)=0 ; x(0)=x_{0}$. So the dynamic equations of firing pin in stage II are:

\begin{tabular}{|c|c|c|c|c|}
\hline No. & Items & $\begin{array}{c}\text { Symb } \\
\text { ol }\end{array}$ & Unit & Value \\
\hline 1 & $\begin{array}{l}\text { Geometric dimensions } \\
\text { (Fig.2) }\end{array}$ & $\begin{array}{c}l_{1} \\
l_{2} \\
\mathrm{e}_{3}=\mathrm{e}_{1}-\mathrm{e}_{2}\end{array}$ & $\begin{array}{l}\mathrm{mm} \\
\mathrm{mm} \\
\mathrm{mm}\end{array}$ & $\begin{array}{c}16.9 \\
44.4 \\
1.2\end{array}$ \\
\hline 1 & $\begin{array}{l}\text { Mass of slide and firing } \\
\text { pin }\end{array}$ & $m_{3,4}$ & $\mathrm{~kg}$ & 0.08 \\
\hline 2 & $\begin{array}{l}\text { Resistance moment of } \\
\text { trigger spring }\end{array}$ & $M_{R S}$ & $\mathrm{~N} / \mathrm{mm}$ & $\begin{array}{c}0.14 \\
10^{-3}\end{array}$ \\
\hline 3 & $\begin{array}{l}\text { Constant factor } \\
\text { characteristic of the spring }\end{array}$ & $k$ & $\mathrm{~N} / \mathrm{mm}$ & 0.65 \\
\hline 4 & Mass of cartridge case & $\mathrm{M}_{\mathrm{vd}}$ & $\mathrm{kg}$ & 0,091 \\
\hline 5 & $\begin{array}{l}\text { Angular velocity of } \\
\text { Trigger }\end{array}$ & $\dot{\alpha}$ & $\mathrm{rad} / \mathrm{s}$ & 1 \\
\hline 6 & $\begin{array}{l}\text { Section area of firing } \\
\text { pin }\end{array}$ & $A$ & $\mathrm{~mm}^{2}$ & 254.7 \\
\hline 7 & $\begin{array}{l}\text { Original length of the } \\
\text { spring }\end{array}$ & $H$ & $\mathrm{~mm}$ & 220 \\
\hline 8 & Density of water & $\rho$ & $\mathrm{kg} / \mathrm{m}^{3}$ & 1030 \\
\hline 9 & Drag coefficient & $C_{d}$ & & 1.2 \\
\hline
\end{tabular}

TABLE 1

INPUT PARAMETERS

$$
\ddot{x}=\left(\frac{-\rho C_{d} A}{2 m_{3,4}}\right) \dot{x}^{2}-\frac{k}{m_{3,4}} x+\frac{H k}{m_{3,4}}
$$

\section{CALCULATION RESULTS AND DISCUSSION}

For the purpose of presenting results of solution, we chose object is the firing mechanism of SPP-1M underwater pistol. The values of the input parameters to analyse are listed in table 1 .

The results calculated of displacement, velocity and acceleration of slide with $\alpha \in\left[270^{\circ}, 320^{\circ}\right]$ in stage I shown in figure 4. The displacement, velocity, acceleration of slide and firing pin with $t \in[0,6] m s$ in stage II shown in figure 5 . We can see maximum velocity of slide in stage I is 18.29 $\mathrm{mm} / \mathrm{s}$ at $\alpha=289.9^{0}$.

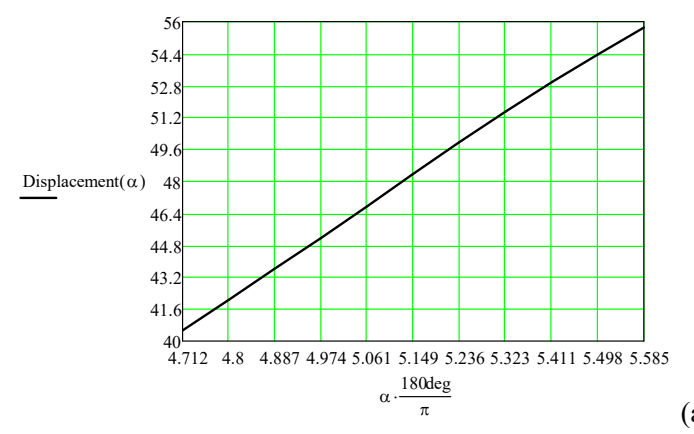

(a)

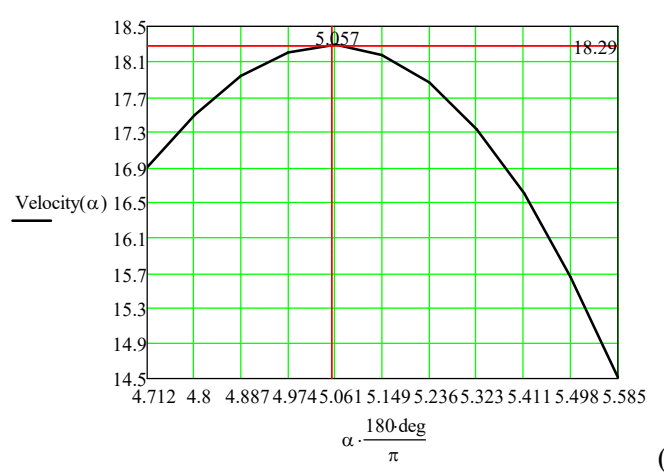

(b)

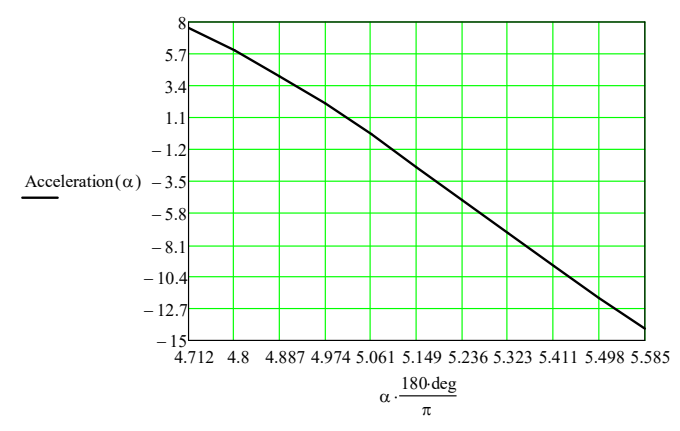

(c)

Figure 4. Displacement, velocity and acceleration of slide in stage I 
a. Displacement; b. Velocity; c. Acceleration

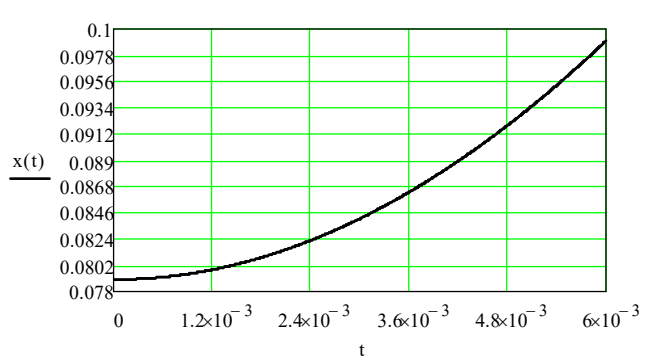

a)

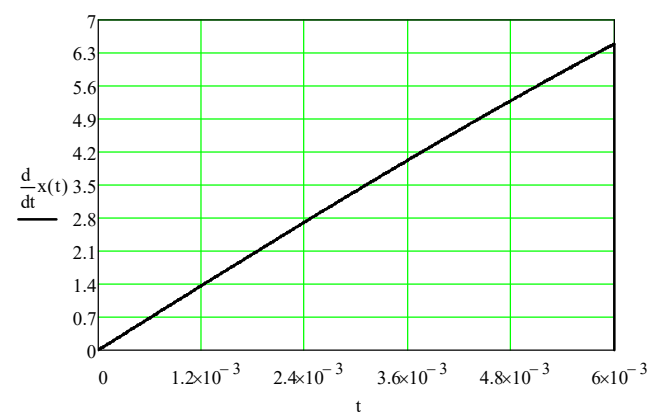

b)

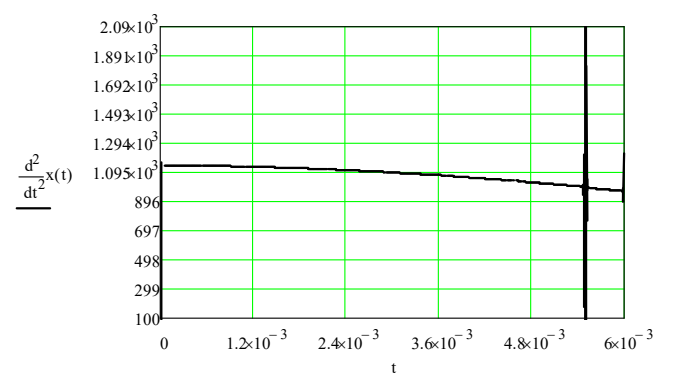

c)

Figure 5. Displacement, velocity and acceleration of slide and firing pin in stage II

a. Displacement; b. Velocity; c. Acceleration

\section{CONCLUSION}

Through analysis of operating characteristics, building mathematical model for analysing the dynamic of dynamic of firing mechanism of underwater pistol and application with the SPP-1M underwater pistol, we see that the calculation results was suitable for the fact. Therefore, the theoretical model of the article has been presented is model have high accuracy and can be applied to design the underwater piston and underwater firearm and amphibious assault rifle. The research results of this paper have been used in the state-level project "Design and manufacture underwater pistol and projectile to serve the water commando forces" code: KC.03.TN08/11-15.

\section{REFERENCES}

[1] "Firearms Technical Trivia", cruffler.com, 2001.

[2] “4.5mm SPP-1M Underwater Pistol”, TsNIITochMash, 2010.

[3] Bộ môn súng pháo, "Nguyên lý thiết kế súng tự động", Tập 3, Trường Đại học Kỹ thuật quân sự, 1977.

[4] Võ Ngọc Anh, "Động lực học vũ khí tự động", Học viện Kỹ thuật quân sự, 1995.

[5] Popenker, Max R, "SPP-1 underwater pistol", world.guns.ru, 2010.

[6] T. O. Zavod(TOZ), "Special Submarine Pistol SPP-1M", Tula Arms Plant, 2010.

[7] "SPP-1 and SPP-1M underwater pistol 4.5mm", www.securityarms.com,2010.

[8] Bộ môn súng pháo, "Nguyên lý thiết kế súng tự động", Tập 1, Trường Đại học Kỹ thuật quân sự, 1974

[9] Nguyễn Đông Anh, "Động lực học hệ vật rắn", Nhà xuất bản xây dựng, 2000 .

[10] P. D.Benzkofer, "Dynamic analysis of shoulder-fired weapons", Proceedings of the seventh U.S.Army symposium on gun dynamics, p205-225, U.S.Army, 1993

[11] A.M. Mackey, "A mathematical model of water entry", AUWE Technical Note, No.636179,1979.

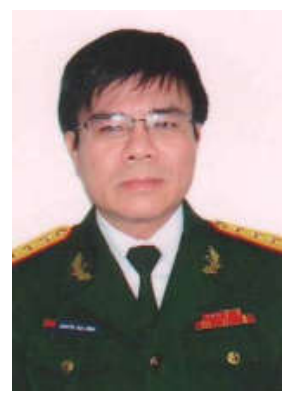

Dung Nguyen Thai was born in Vinh Phuc Province, Viet Nam in 1966. He received the B.S. and M.S. degrees in weapon engineering from the Military technical Acedemy, Viet Nam, in 1990 and the $\mathrm{Ph} . \mathrm{D}$. degree in mechanical engineering, in 2002.

From 2001 to 2004, he was a Lecturer with the Department of Weapons, Faculty of Weapons, Military Technical Academy. Since 2010, he has been an Asscociate Professor. He is the author of nine books, more than 40 articles. His research interests include design and improvement of guns and rocket motor. He is Dean of the Faculty of Weapons and Director of the Technical Center for Weapons, Military Technical Academy.

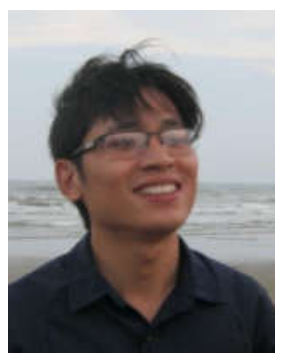

Hung Nguyen Van was born in Thanh Hoa Province, Viet Nam in 1985 . He received the B.S. and M.S. degrees in weapon engineering from the Military technical Acedemy, Viet Nam, in 2009. He is lecturer of the Department of Weapons, Faculty of Weapons, Military Technical Academy. He is the author of three books, more than 10 articles. His research interests include design of special ammunition and guns. 


\title{
Phân tích động lực học cơ cấu phát hỏa của súng ngắn bắn dưới nước
}

\author{
Nguyễn Thái Dũng, Nguyễn Văn Hưng
}

Tóm tắt - Tính toán và phân tích động lực học của cơ cấu phát hỏa là một vấn đề rất quan trọng trong tính toán thiết kế súng ngắn bắn dưới nước. Trên cơ sở phân tích hoạt động của súng ngắn dưới nước, bài báo trình bày một mô hình lý thuyết để phân tích động lực cơ cấu phát hỏa súng ngắn bắn dưới nước có kể đến ảnh hưởng do lực cản của nước tác động lên khóa nòng và kim hỏa. Kết quả nghiên cứu của bài báo có thể ứng dụng trong tính toán thiết kế súng ngắn và súng tiểu liên bắn dưới nước.

Tù khóa - Động lực học, Cơ cấu phát hỏa, Lụ̣c cản của nước, Súng ngắn bắn dưới nước. 